Edyta Żyrek-Horodyska

Uniwersytet Jagielloński

ORCID: 0000-0002-7276-1736

\title{
Wszystko za Everest Jona Krakauera w kontekście głównych założeń Nowego Nowego Dziennikarstwa
}

\begin{abstract}
Streszczenie
Celem artykułu jest usytuowanie reportażu Wszystko za Everest Jona Krakauera u kontekście głównych założeń Nowego Nowego Dziennikarstwa. W szkicu u sposób krytyczny omówiono najważniejsze cechy tego paradygmatu, nawiązującego z jednej strony do twórczości amerykańskich muckrakerów z początków XX wieku, z drugiej - do prac amerykańskich reporterów z lat sześćdziesiątych i siedemdziesiątych XX stulecia. Szczegółoue badania poświęcono twórczości Krakauera, którego tom Wszystko za Everest został scharakteryzowany jako dziennikarska forma synkretyczna, łącząca elementy autoreportażu, reportażu immersyjnego oraz paraliteratury.
\end{abstract}

Słowa kluczowe: Jon Krakauer, Wszystko za Everest, Nowe Nowe Dziennikarstuo, immersja, reportaż.

\section{Into Thin Air by Jon Krakauer in the Context of the Main Features of New New Journalism}

\begin{abstract}
The aim of this article is to present Jon Krakauer's reportage Into Thin Air in the context of the main features of New New Journalism. The author critically discusses the most important elements of this paradigm, which refers on the one hand to the legacy of muckrakers from the beginning of 20th-century, and on the other hand - to the tradition of American reporters from the 1960s and 1970s. Detailed research was devoted to the Krakauer's book Into Thin Air, which has been described as a journalistic syncretic form, combining elements of auto-reportage, immersive reportage and paraliterature.
\end{abstract}

Keywords: Jon Krakauer, Into Thin Air, New New Journalism, immersion, reportage. 


\section{Wprowadzenie}

„Istnieją takie sfery życia, do których dziennikarstuo wciąż nie może z łatwością dotrzeć, szczególnie ze względu na fakt naruszenia prywatności, i to ułaśnie w tym obszarze w przyszłości będzie mogła się rozwijać powieść" ${ }^{-}$konstatował amerykański reporter Tom Wolfe w przedmowie do opublikowanej w 1973 roku antologii The New Journalism. Kiedy śledzimy póńniejszy rozwój amerykańskiej żurnalistyki, można zauważyć, że te profesjograficzne uwagi jednego z najważniejszych twórców Nowego Dziennikarstua w pewnym stopniu zostały zrewidowane. Dowodem na to są chociażby dynamicznie rozwijające się w kolejnych dekadach projekty dziennikarskie oparte na immersji i empatii, reportaż intymny czy rozmaite formy autoreportażowe i paradziennikarskie, będące świadectuem ustawicznego mącenia dziennikarskich i literackich gatunków. Szczególne uprzywilejowanie przywołanych tu strategii zapisywania świata można dostrzec wśród autorów, których twórczość wpisuje się w paradygmat tak zwanego Nowego Nowego Dziennikarstua (dalej: NND), określanego nieco przewrotnie przez jednego z publicystów „New York Times” mianem „gonzo XXI wieku”.

Ten szkic poświęcono omówieniu głównych założeń uspomnianego tu nurtu, który nie odnosi się - co trzeba uyraźnie podkreślić już na ustępie - do jakiejś precyzyjnie ustrukturyzowanej i wyodrębnionej dziennikarskiej formacji. Etykieta NND nie jest oficjalnym szyldem żadnej społeczności; funkcjonuje raczej jako sui generis nadrzędna struktura scalająca, którą - jak pisze Robert S. Boynton - można objąć żurnalistów przełomu XX i XXI wieku, posługujących się zbliżonym rezerwuarem technik gromadzenia i przekazywania informacji. W artykule pragnę przyjrzeć się bliżej twórczości Jona Krakauera, wpisującej się u ramy uspomnianego tu paradygmatu, obejmującego teksty ,rygorystycznie udokumentowane, pod względem psychologicznym błyskotliwe, pod względem socjologicznym wyszukane i przejawiające polityczną świadomość"3. Sygnowany nazwiskiem Amerykanina tom Wszystko za Everest ${ }^{4}$ wydaje się modelowym wręcz przykładem praktyk twórczych z jednej strony szeroko inspirowanych nowodziennikarską poetyką, z drugiej - umiejętnie rozszerzających wachlarz charakterystycznych dla niej środków artystycznego obrazowania.

Przyjęta przeze mnie metoda analizy treści pozwoli - jak ustępnie zakładam - usytuować Wszystko za Everest w kontekście głóunych założeń NND. Pomoże także ujaunić i udokumentować dominanty semantyczne tekstu oraz uyszczególnić warsztatowe preferencje jego twórcy. Korzystając z metody close Reading, postaram się uykazać, że wspomniana książka jest - po pierusze - przykładem autoreportażu, którego główną

\footnotetext{
1 T. Wolfe, The New Journalism, Harper and Row, New York 1973, s. 35, przeł. E.Ż.-H.

2 J. Shafer, „The New New Journalism”: Gonzos for the 21st Century, „, The New York Times”, https://wuw.nytimes.com/2005/03/20/books/review/the-new-new-journalism-gonzos-for-the-21st-century.html (dostęp: 30.11.2020).

${ }^{3}$ R. Boynton, New New Journalism. Conversations with America's Best Nonfiction Writers on Their Craft, Random House, New York 2005, s. XI, przeł. E.Ż.-H.

${ }^{4}$ Por. J. Krakauer, Wszystko za Everest, przeł. K. Palmouska, Wydawnictuo Czarne, Wołowiec 2015.
} 
oś fabularną stanowią przeżycia i doświadczenia samego autora. Można - po drugie odczytywać ją w kategoriach reportażu immersyjnego, bazującego na bezpośrednim zaangażowaniu piszącego $\mathrm{w}$ dokumentowaną rzeczywistość. W końcu po trzecie, praca ta $-z$ racji stosowania przez Krakauera określonych chuytów artystycznych w sposobie przedstawiania tematyki górskiej - wpisuje się u schemat paraliteratury, świadomie estetyzującej dziennikarską narrację. Wykorzystywane przez reportera rozwiązania fabularne, opierające się na retrospekcjach, retardacjach, rezygnacji z powściągliwego języka i silnym dramatyzowaniu akcji, ciążą nie tyle w stronę stricte dokumentarnego, ile artystycznego wzorca, upodabniając Wszystko za Everest do powieści sensacyjnej.

\section{Czym jest Nowe Nowe Dziennikarstwo?}

W książce pt. The New New Journalism... ${ }^{5}$ Boynton uskazał na ukonstytuowanie się na przełomie XX i XXI wieku grupy żurnalistów, których zawodowy warsztat cechuje głęboka immersja u opisywaną rzeczywistość, przywiązanie do detalu, zażyłość z portretowanymi bohaterami, ekspresywność stylu i szeroka perspektywa, z jakiej ukazują dokumentowane fakty. Reporterzy tacy jak Krakauer, Jane Kramer, Ted Conover, Eric Schlosser, Lawrence Wright czy Richard Preston uprawiają, zdaniem Boyntona, osobliwy rodzaj dziennikarskiego rzemiosła, nie zważając na medialną presję czasu i nie poddając się dyktatowi newsa. Działając niejako wbrew mediom dążącym do skrótowości i lakoniczności, tworzą wartościowe, pogłębione materiały, nobilitujące kategorię literackości, a przy tym stanowiące źródło interesujących eksperymentów formalnych.

Znamienne, że Boynton - jako autor przemowy do książki będącej de facto zbiorem wywiadów z amerykańskimi reporterami - już w pierwszych słowach swojego wywodu w intertekstualnym geście przywołuje inną, niezwykle ważną dla kultury amerykańskiej przedmowę. Chodzi mianowicie o szkic, jaki Wolfe zamieścił u 1973 roku w antologii The New Journalism, wykładając u nim główne założenia Nowego Dziennikarstwa. Choć trudno jednoznacznie stwierdzić, czy wywód Boyntona ma równie szeroko zakrojone ambicje, faktem jest, że dąży on do uchuycenia i sportretowania pewnego osobliwego fenomenu, jaki kilka dekad po generacji Normana Mailera pojauił się na rynku amerykańskiej prasy. „Łącznikiem” pomiędzy antologią Wolfe’a a późniejszym tomem Boyntona stał się Gay Talese, którego nazwisko figuruje w obu pracach, stanowiąc suego rodzaju pomost, reporterskie continuum między zanurzoną w kontrkulturze lat sześćdziesiątych i siedemdziesiątych XX wieku koncepcją New Journalism a uwikłanym w dylematy późnej nowoczesności paradygmatem New New Journalism.

Zdaniem Boyntona NND opiera się na jednoczesnym transferze uzorców z duóch nowodziennikarskich tradycji, umiejętnie absorbując najważniejsze ingredienty każdej z nich. Jednym z punktów odniesienia jest uspomniane już Nowe Dziennikarstwo lat sześćdziesiątych i siedemdziesiątych XX wieku, które kontestowało pozorny

\footnotetext{
${ }^{5}$ Por. R. Boynton, op. cit.
} 
obiektyuizm i tradycyjne sposoby relacjonowania zdarzeń. Drugim filarem jest natomiast idea Nowego Dziennikarstwa zakorzeniona w tradycji prasy z przełomu XIX i XX wieku, stawiającej sobie za cel podnoszenie ważnych kwestii społecznych oraz ujawnianie wyzysku i nieprawidłowości (tzw. muckraking) ${ }^{6}$. W twórczo agregujących oba te obszary pracach Nowych Nowych Dziennikarzy pouracają więc ze wzmożoną siłą tematy chętnie eksplorowane w prasie przez reporterów z początków XX wieku, takie jak niesprawny system więziennictwa, ubóstwo, przemoc, społeczne uyklucze$n^{7}{ }^{7}$. Prezentowane są one jednak przy użyciu eksperymentalnych technik i narzędzi, właściwych reporterom II połowy XX wieku. Mówiąc najprościej, w NND - jak pisze Wiesław Godzic - trzeba „[...] widzieć kontynuację polegającą na zmaksymalizowaniu środków dziennikarskich dostępnych poprzedniej generacji”.

Podkreślić należy, że ta użyteczna, choć dyskusyjna formuła jest przez medioznawców z kilku względów poddawana krytyce. Współcześni oponenci stawiają NND zarzut zbytniej nieprecyzyjności. Dziennikarze przyporządkowani przez Boyntona do tej wysoce synkretycznej konwencji nie wypracowali bowiem żadnego wspólnego programu i manifestu, a stosowane przez nich techniki immersyjne czy dziennikarstwo wcieleniowe funkcjonowały u światowej żurnalistyce już kilka dekad wcześniej. Wątpliwości wzbudza róunież sama nazwa. Alba Sabaté Gauxachs wskazuje jeszcze przynajmniej kilka innych określeń, które mają zbliżony do NND zakres semantyczny: literary journalism, longform journalism, narrative literary journalism ${ }^{9}$. Broniąc swej koncepcji, Boynton sugeruje, że reporterzy ci pod wieloma uzględami kontynuują założenia wypracowane przez ich wielkich poprzedników. Ich eksperymentalne podejście do tematu - jak pisze badacz - dotyczy nie tyle języka czy stylu, ile przede wszystkim technik pozyskiwania informacji i maksymalnego zbliżenia się do bohaterów ${ }^{10}$. Aby dobrze zilustrować ten fakt, podaje kilka interesujących przykładów, podkreślając, że reporterzy przełomu XX i XXI wieku

[...] opracowali innowacyjne strategie immersyjne (na potrzeby Newjack Ted Conover zatrudnił się jako strażnik więzienny; by napisać Rolling Nowhere zdecydował się żyć jako włóczęga) i wydłużyli czas, który spędzali na przygotowaniu reportaży (Leon Dash podążał

\footnotetext{
${ }^{6}$ Por. L. Weinberg, Introduction [w:] The Muckrakers, red. A. i L. Weinberg, University of Illinois Press, Urbana-Chicago 2001, s. XVI; W. Adamczyk, Amerykańskie archetypy dziennikarstwa śledczego, Wydawnictuo Naukoue Wydziału Nauk Politycznych i Dziennikarstwa Uniwersytetu im. Adama Mickiewicza u Poznaniu, Poznań 2008.

${ }^{7}$ Por. B. Burke, P. Leckman, A. Sturzen, K. Van Vlack, H. Villanueva, Lessons from New New Journalism, „Arizona Anthropologist” 2006, nr 17, s. 76-90.

${ }^{8}$ W. Godzic, Widzieć świat przez okulary. Dziennikarstwo na serio i to niepoważne [w:] Media.pl. Badania nad mediami w Polsce, red. T. Bielak, G. Ptaszek, Libron, Kraków 2016, s. 185.

${ }^{9}$ Por. A. Sabaté Gauxachs, Slow Media and Religion. The New New Digital Journalism as an Agora for Understanding, Doctoral Thesis. Barcelona 2020, s. 23, https://wuw.tdx. cat/bitstream/handle/10803/668952/Tesi_Alba_Sabate.pdf?sequence=2\&isAllowed=y (dostęp: 1.12.2020).

${ }^{10}$ Por. R. Boynton, op. cit., s. XIII.
} 
za postaciami opisanymi w Rosa Lee pięć lat; Adrian LeBlanc dokumentowała uydarzenia z myślą o Random Family przez prawie dekadę; prawie tyle samo zajęła Jonathanowi Harrowi praca nad A Civil Action) ${ }^{11}$.

Interesującym kontekstem interpretacyjnym służącym zobrazowaniu technik pozyskiwania informacji przez przedstawicieli NND jest przywoływana przez Boyntona koncepcja negative capability, którą w liście z 21 grudnia 1817 roku wyłożył angielski romantyk John Keats. Owa „negatyuna zdolność”, rozumiana przez poetę jako akceptacja niepewności i wątpliwości, pogodzenie się z istnieniem sfery niedostępnej ludzkiemu poznaniu, ma - jak pisze badacz - także swoją „dziennikarską wersję"12. Reporterzy - podobnie jak obdarzeni szczególnymi kompetencjami romantyczni twórcy, sięgając po techniki immersyjne, starają się niejako dotrzeć do tej przestrzeni „pomiędzy”, ulokowanej na styku rzeczywistości i ludzkiej percepcji. Chcą i mogą zobaczyć więcej, jako że potrafią wykroczyć poza tradycyjne formy zdobywania informacji.

Aby zobrazować bogactwo tematów i metod wykorzystywanych przez amerykańskich reporterów przełomu XX i XXI wieku, warto choć szkicowo przedstawić najważniejsze dokonania kilkorga spośród nich. Ważną postacią na długiej liście nazwisk wskazywanych przez Boyntona jest Alex Kotlowitz - autor między innymi uydanej w 1999 roku książki The Other Side of the River... podejmującej temat ubóstua i rasizmu w USA w kontekście tajemniczej śmierci Erica McGinnisa - czarnoskórego nastolatka. Temat wykluczenia interesował również Adrian Nicole LeBlanc w opublikowanym w 2003 roku reportażu Random Family. Dziennikarka nakreśliła u nim efekty swoich kilkunastoletnich obserwacji, prowadzonych w nowojorskim Bronxie wśród ubogich rodzin mierzących się z problemami narkotykouymi. Zbliżoną metodę pracy wybrał Leon Dash, przygotourując reportaż pt. Rosa Lee... z 1996 roku. Dziennikarz opowiada w nim o czterech latach, w trakcie których przyglądał się codziennemu życiu ubogiej czarnoskórej kobiety i jej rodziny. Z kolei Eric Schlosser - autor książki Reefer Madness... z 2003 roku - zasłynął jako reporter śledczy. Ujawnił i udokumentował funkcjonowanie w USA sprawnie działającego podziemia, w którym kuitła prostytucja, nielegalna praca imigrantów i handel marihuaną. William Langewiesche w Cutting for Sign sportretował trudną sytuację na pograniczu amerykańsko-meksykańskim. Ted Conover z kolei zasłynął między innymi pracą Newjack. Guarding Sing Sing, w której ucielił się w funkcjonariusza więziennego i z tej perspektywy opisał problemy amerykańskiego więziennictua, w róunym stopniu deprawującego skazanych, co pracujące tam osoby.

Poszukując jakiejś uniwersalizującej formuły, która objąć mogłaby tak zróżnicowane pod uzględem warsztatouym prace, Godzic stwierdza, że teksty tworzone w ramach paradygmatu NND są „[...] śmiałe, ekspresyjne i totalne zarazem. Właściwie mówi się o innowacyjnych technikach zanurzania w opisywanym świecie"13. Nowatorskie strategie stosowane przez reporterów przyczyniają się do tego, że ich książki zyskują

\footnotetext{
${ }_{11}$ Ibidem, przeł. E.̇̇.-H.

${ }^{12}$ Por. ibidem, s. XXVII.

13 Por. W. Godzic, op. cit., s. 184.
} 
status bestsellerów i są tłumaczone na wiele języków. Tego typu publikacje wykraczają poza obszar zainteresowań mieszkańców jednego kraju; poruszają bowiem - podobnie jak twórczość artystyczna - uniwersalne problemy. Można zatem zaryzykować stwierdzenie, że u takim ujęciu twórczość non-fiction staje się współcześnie „de facto literaturą naszych czasów"14.

\section{Kariera dziennikarska Jona Krakauera}

Na tle wspomnianych reporterów dorobek Krakauera uyróżnia się przynajmniej z kilku powodów. Zauważyć należy, że urodzony u 1954 roku amerykański dziennikarz zyskał już międzynarodową sławę, a jego książki reportażoue - takie jak Wszystko za Everest, Missoula. Gwatty w amerykańskim miasteczku uniwersyteckim, Pod sztandarem nieba. Wiara, która zabija, Wszystko za życie czy Eiger wyśniony - znane są także polskiemu czytelnikowi. Popularność przyniósł mu ponadto film Everest z 2015 roku, opowiadający o wyprawie na najuyższą górę świata, w której Amerykanin brał udział.

Pieruszą ważną książką w bogatym dorobku reporterskim Krakauera był Eiger Dreams... z 1992 roku. Tom ten - zapowiadający niejako późniejszy reportaż Wszystko za Everest - jest zbiorem kilkunastu tekstów prasowych traktujących o relacjach człowieka z górami. Kolejną głośną publikacją był Into the Wild, w której Krakauer przyjął perspektyuę rekonstruktora zdarzeń. Na postawie rozmaitych źródeł odtworzył historię Chrisa McCandlessa - amerykańskiego podróżnika, który - zainspirowany twórczością Jacka Londona - wyruszył w kilkuletnią podróż po Ameryce Północnej, kończąc swe życie na Alasce. Rok 1996 przyniósł publikację Into Thin Air... Siedem lat później ukazał się tom Under the Banner of Heaven... traktujący o zbrodni, jaką z pobudek religijnych popełniono w mormońskiej uspólnocie w 1984 roku. W roku 2009 Krakauer wydał Where Men Win Glory: The Odyssey of Pat Tillman - reportaż biograficzny opowiadający o życiu Pata Tillmana - amerykańskiego sportouca, który po 11 urześnia 2001 roku ustąpił do amerykańskiej armii, a trzy lata później został zamordowany u Afganistanie. W roku 2011 ukazał się reportaż Three Cups of Deceit demaskatorska opowieść o nieuczciuych praktykach nominowanego do pokojowej nagrody Nobla Grega Mortensona. Cztery lata później Krakauer opublikował książkę Missoula. Rape and the Justice System in a College Town, ujauniając w niej akty przemocy wobec studentek uniwersytetu w Missouli oraz niewydolność systemu prawnego.

Już nawet ten - rzecz jasna - niepełny przegląd prac Krakauera, który należałoby uzupełnić jeszcze chociażby o liczne reportaże prasowe, publikowane na szpaltach „Outside”, pozwala przynajmniej na kilka ogólniejszych obserwacji. Uwagę zuraca, po pierusze, uprzywilejowanie przez reportera dziennikarstua demaskatorskiego, nawiązującego do praktyk stosowanych w USA na przełomie XIX i XX wieku przez muckrakerów. Po drugie, odnotować warto, że Krakauer na bohaterów suych prac

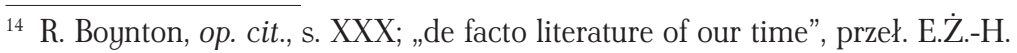


zuykle wybiera wyraziste postaci, silnych indywidualistów, stosując przy tym dwa typowe dla NND - modele fabularyzowania zdarzeń. Z jednej strony opowiada o „zwykłym życiu niezuykłego człowieka”, z drugiej - dokumentuje historię „niezwykłego życia zuykłego człowieka"15. Po trzecie, podkreślić należy zogniskowanie wielu prac Krakauera wokół tematyki alpinistycznej, co wynikać może zarówno z osobistych pasji dziennikarza, jak i z możliwości odnalezienia właśnie w tym obszarze postaw i wartości z punktu widzenia mediów szczególnie interesujących: zmagań wybitnych jednostek z nieokiełznaną naturą; manifestacji buńczucznego indywidualizmu i heroizmu, urychodzenia przez człowieka poza jego biologiczne i psychologiczne ograniczenia.

W rozmowie z Boyntonem Krakauer charakteryzuje metody swojej pracy. W profesjograficznych passusach konsekwentnie kreuje swój wizerunek jako rzetelnego specjalisty, który z ogromnym zaangażowaniem podchodzi do wykonywanego zawodu, zdecydowanie stroniąc przy tym od dziennikarskiej pogoni za newsem. Autor opiera swój warsztat na uważności. Przyznaje, że pisanie książek poprzedza każdorazowo dogłębny i czasochłonny research, stanowiący dla niego fundament pracy reportera: „Lubię przygotowywać dokumentację [...]. Zausze rozpoczynam od przeczesywania katalogów bibliotecznych, księgarń, od sprzedauców trudno dostępnych książek [...]”'16.

W wielu pracach Krakauera swoistym kontrapunktem dla reporterskiego przywiązania do rekonstrukcji staje się dogmat naoczności, a także możliwość rzeczywistego wejścia w opisywane środowisko. Choć dziennikarz chętnie korzysta ze źródeł zastanych (oficjalne dokumenty, pamiętniki, korespondencja), dzięki którym jest u stanie dogłębnie prześledzić i przeanalizować dany problem, duże znaczenie ma dla niego możliwość towarzyszenia bohaterom, stawania z nimi niejako ramię $\mathrm{w}$ ramię. Stąd tak istotną rolę w jego pracach odgrywa dziennikarska immersja, konstytuująca ramę narracyjną między innymi tomu Wszystko za Everest.

\section{Wszystko za Everest w kontekście głównych założeń NND}

Reportaż Wszystko za Everest jest pokłosiem podróży do Nepalu, na którą w marcu 1996 roku Krakauer został wysłany przez redakcję magazynu „Outside”. Zamiarem dziennikarza było wówczas dołączenie do uyprawy komercyjnej, która pod kierownictuem Roba Halla postawiła sobie za cel zdobycie najwyższego szczytu świata ${ }^{17}$. Krakauer pragnął udokumentować kulisy tego przedsięwzięcia, skupiającego nie tylko profesjonalnych himalaistów, lecz także uspinaczy-amatorów, za odpowiednią opłatą otrzymujących możliwość dołączenia do ekspedycji. 10 maja na szczycie Mount Everest stopę postawiło sześciu członków wyprawy oraz dwóch Szerpów. Radość nie trwała jednak długo: gdy wspinacze schodzili z góry, rozpętała się niebezpieczna burza śnieżna. Fakt, że ekspedycja nie była należycie przygotowana do ataku szczytowego,

\footnotetext{
${ }^{15}$ Ibidem, s. 361.

${ }^{16}$ Ibidem, s. 163, przeł. E.Ż.-H.

17 Por. J. Krakauer, op. cit., s. 11.
} 
a poszczególni jej członkowie nie uspółpracowali ze sobą we właściuy sposób, przyczynił się do śmierci kilku osób i zainicjował ważne dyskusje na temat uczestniczenia nieprofesjonalnych wspinaczy w tak wymagających przedsięwzięciach.

Naszkicowany tu w koniecznym skrócie przebieg majowego ataku na Mount Everest stanowi kanwę reportażowej opowieści Krakauera, która - co ciekawe - nie zakończyła się uraz z postawieniem przez reportera ostatniej kropki, lecz miała swoją kontynuację w postaci prac innych autorów, nie zawsze podzielających punkt widzenia Amerykanina. Żywa dyskusja, jaką wywołało pojawienie się w księgarniach tomu Wszystko za Everest, dotyczyła przede wszystkim kwestii dziennikarskiego obiektywizmu i rzetelności atakującego szczyt Krakauera. Temat ten podjęli między innymi Anatolij Bukriejew oraz G. Weston DeWalt w opublikowanej rok później pracy pt. Wspinaczka ${ }^{18}$. Do ich polemicznego wystąpienia Krakauer odniósł się w następujący sposób:

Jak się okazało, Bukriejew poczuł się mocno urażony sposobem, w jaki został sportretowany u mojej książce Wszystko za Everest, dlatego też znaczna część Wspinaczki jest poświęcona obronie działań podejmowanych przez niego podczas wyprawy. Przy okazji zakwestionowana została rzetelność relacji, a moja dziennikarska uczciuość postawiona pod znakiem zapytania ${ }^{19}$.

Pozostawiając na boku przebieg sporu pomiędzy między autorami-himalaistami i wagę przywoływanych przez obie strony argumentów, pragnę zurócić uwagę na zasadniczą oś tego sporu. Dotyczył on bowiem w gruncie rzeczy dziennikarskich imponderabiliów, tj. kwestii rzetelności reportera, jego zaangażowania (bądź zdystansowania) wobec opisywanych zdarzeń, możliwości formułowania ocen, manifestowania określonego nastawienia do poszczególnych bohaterów oraz stosowania środków paraartystycznych. Warto zatem - starając się usytuować Wszystko za Everest w kontekście głównych założeń NND - spojrzeć na ten tekst właśnie w kontekście rysujących się $w$ tym sporze trzech perspektyw, zogniskowanych wokół autobiograficzności tomu, immersyjnych narzędzi stosowanych przez reportera oraz quasi-literackiej poetyki samego tekstu.

\section{Autoreportaż}

Autoreportaż - jako forma uwypuklająca u dziennikarskiej narracji przeżycia i doświadczenia reportera ${ }^{20}$ - jest zakorzeniony w nowodziennikarskiej poetyce. Autobiografizowanie dyskursu pozwala piszącemu na uporządkowanie ważnych dla niego faktów i osadzenie ich w szerszym kontekście. Azymut na autoreportaż w tomie Wszystko za Everest został nakierowany bardzo wyraźnie. Krakauer przyznaje to już we ustępie

\footnotetext{
${ }_{18}$ Por. A. Bukriejew, G.W. DeWalt, Wspinaczka, przeł. P. Paulaczek, Wydawnictuo Dolnośląskie, Wrocław 2015.

19 J. Krakauer, op. cit., s. 385.

${ }^{20}$ Por. E. Żyrek-Horodyska, Reportaż biograficzny czy biografia reportażowa? Refleksje genologiczne i analiza przypadku, „Autobiografia” 2018, nr 2, s. 173.
} 
do tomu, gdzie podkreśla, że praca ta była przygotowywana z pobudek nie tyle stricte dziennikarskich, informacyjnych, ile osobistych. Dla autora książka pełnić miała bowiem funkcję terapeutyczną:

Myślałem, że napisanie tej książki pomoże usunąć Everest z mojego życia, oczyścić mnie z niego.

Oczyuiście tak się nie stało. Co więcej, zgadzam się z tuierdzeniem, że gdy autor pisze coś w akcie katharsis - jak w moim przypadku - często dzieje się to ze szkodą dla czytelnika ${ }^{21}$.

Krakauer nie kryje, że oddawany u ręce odbiorcy tom - przepełniony żywiołem dygresyjnym - miał odgrywać podobną do autobiografii rolę: winien scalić rozrzucone fakty w jedną koherentną opowieść, pozwolić autorowi odnaleźć sens w wydarzeniach pozornie go pozbawionych. Znamienne, że szansę na to Krakauer upatruje nie w ograniczonym precyzyjnymi limitami materiale prasouym, lecz właśnie u tak ważnej z punktu widzenia NND obszernej formie reportażu książkowego.

O wyznaczającej dyskursywną ramę obecności dziennikarza na scenie zdarzeń przypominają czytelnikowi przede wszystkim: pierwszoosobowa narracja, eksponowanie faktu, że Krakauer był pełnopraunym uczestnikiem opisywanej wyprawy, jak również liczne reminiscencje o charakterze autobiograficznym, które pozwalają usytuować pracę reportera u obszarze nie tylko genologii dziennikarskiej, lecz także literatury dokumentu osobistego. Piszący prezentuje się przed czytelnikiem u dwojaki sposób: z jednej strony jako doświadczony uspinacz, który chętnie powraca pamięcią do suych największych sukcesów i przeżywa dylematy moralne związane ze śmiercią uspółtowarzyszy, z drugiej - jako reporter, który winien u sposób możliwie dokładny i rzeczowy dać śuiadectwo. Zderzenie obu tych perspektyu sprawia, że omawiany tu reportaż absorbuje elementy autobiografii i dziennika intymnego, łącząc je z publicystyczną żarliwością. Warto przywołać choć jeden charakterystyczny fragment, uwypuklający wysoce osobisty charakter opowieści:

Gdy piszę te słowa, od powrotu z Nepalu minęło pół roku. Przez cały ten czas, każdego dnia, tylko przez dwie, może trzy godziny nie myślałem o Evereście. Nie mam wytchnienia nawet w nocy. Obrazy ze wspinaczki i następnych dni wciąż przenikają moje sny ${ }^{22}$.

Wszystko za Everest dostarcza czytelnikowi wielu informacji na temat życia autora. Jest jednak również szczegółouym dokumentem jego emocji, zapisem formułowanych przez niego ocen, uwag o charakterze profesjograficznym. Tekst zawiera wiele impresji i anegdot głęboko zanurzonych w osobistych doświadczeniach piszącego. Zauważyć można zatem adaptowanie tej książki do uyznaczników reportażu intymnego, definiowanego przez Kingę Siewior jako tekst, ,[...] w którym uyraźne prawo głosu

\footnotetext{
${ }^{21}$ J. Krakauer, op. cit., s. 13.

${ }^{22}$ Ibidem, s. 374.
} 
zyskuje osobiste doświadczenie reportera"23, dzielącego się z czytelnikiem szczegółami ze swojego życia. Krakauer z ogromną pieczołowitością eksploruje sferę fizjologiczną, ale także ujawnia przed czytelnikiem swe stany emocjonalne. W ten sposób staje się jednocześnie narratorem i bohaterem reportażowego tomu.

\section{Reportaż immersyjny}

Dziennikarstwo immersji ${ }^{24}$ zyskuje popularność jako alternatywa dla tradycyjnego, „obiektywizującego" dyskursu medialnego, opartego na zdystansowanym oglądzie i relacjach z drugiej ręki. Ich miejsce obecnie zajmuje często przełamująca dokumentarne konwencje opowieść reportera będącego częścią opisywanej historii, uspółtworzącego ją, uspółuczestniczącego w wydarzeniach i dążącego do ujawnienia faktóu, do których z różnych względów nie byłby w stanie dotrzeć w inny sposób. Jak pisze Robin Hemley:

Innym określeniem dla dziennikarstwa immersyjnego jest dziennikarstuo uczestniczące. Jakkolwiek by nazwać tę pracę, wykonujący ją autor angażuje się w wydarzenie, o którym chce napisać, aby uzyskać możliwość poznania go od środka ${ }^{25}$.

Reporter przenika (u sposób jawny bądź nieujawniony) do środowiska, które stara się sportretować, dążąc do tego, by przedstawiona przez niego relacja wywoływała wśród odbiorców wrażenie naoczności.

Immersyjne nastawienie Krakauera zasadza się na całkowitym wchodzeniu w świat i permanentnym przełamywaniu granic pomiędzy sferą prywatną a zawodową. Mocne autorskie ,ja” nie traci przy tym suego głównego celu, jaki przyświeca zazuyczaj opartym na immersji projektom dziennikarskim. Chodzi mianowicie o „ujawnianie”, „odkrywanie”, „demaskowanie” tego, co hermetyczne środowisko górskie chciałoby raczej pozostawić w sferze kulis. Krakauer sygnalizuje to w Postscriptum dołączonym do tomu, gdzie odnosi się do kontrowersji, jakie uśród wspinaczy wywołała jego książka:

Mocno wierzę u to, że miałem obowiązek - wobec tych, którzy przeżyli, wobec rodzin będących w żałobie, wobec historii i wobec współtowarzyszy, którzy nie wrócili do domu dostarczyć pełny raport z tego, co się wydarzyło na Evereście u 1996 roku, nie patrząc na to, jak ten raport będzie przyjęty ${ }^{26}$.

W przyuołanym tu fragmencie ujawnia się przywiązanie NND do tradycyjnie rozumianej misji dziennikarskiej i wartości promowanych przez muckrakerów, które każą reporterowi służyć społeczeństuu, piętnować słabości obowiązującego systemu, a nawet dążyć do zainicjowania konkretnych zmian.

${ }^{23}$ K. Siewior, Ślimak, śrubeczka i śmierć. Reportaż intymny Mariusza Szczygła, ,Teksty Drugie" 2019, nr 6, s. 65.

${ }^{24}$ Por. P. Walters, Ted Conover and the Origins of Immersion in Literary Journalism, „Literary Journalism Studies" 2017, nr 9, s. 9-33.

${ }^{25}$ R. Hemley, A Field Guide for Immersion Writing. Memoir, Journalism, and Travel, The University of Georgia Press, Athens-London 2012, s. 55, przeł. E.Ż.-H.

${ }^{26}$ J. Krakauer, op. cit., s. 407. 
W tomie Wszystko za Everest Krakauer staje się częścią opisywanej społeczności, przynależy do niej, nie tracąc przy tym statusu outsidera. Tak samo jak bohaterowie książki doświadcza trudów wyprawy i walczy z chorobą uysokościową, nie ukrywa swoich sympatii do niektórych członków ekspedycji i dystansu wobec pozostałych. Opisując uczestników komercyjnej uyprawy na Mount Everest, zauważa nawet, że jego doświadczenie i przygotowanie w wyraźnym stopniu przeuyższają kompetencje pozostałych osób w zespole:

Nie byłem pewien, co sądzić o moich współtowarzyszach. Wzbudzali we mnie pewien niepokój. Wyglądem i doświadczeniem u żadnej mierze nie przypominali uspinaczy z praudziwego zdarzenia, z którymi zuykle jeździłem u góry. [...] Nie miałem [...] wiele wspólnego z kimkoluiek z nich, z wyjątkiem Douga ${ }^{27}$.

Krakauer prezentuje się jako pełnoprawny uczestnik grupy Adventure Consultants, a nie zdystansowany reporter, przyglądający się li tylko działaniom poszczególnych wspinaczy. Podkreśla swą przynależność do zespołu, określając jego członków mianem „kolegów”28, „towarzyszy”29. Nierzadko sięga także po narrację utrzymaną u pieruszej osobie liczby mnogiej, mającą dodatkowo podkreślić fakt, że reporter pokonywał dokładnie tę samą trasę, jaką przebywali jego towarzysze. Zdradza jednak przy tym niezwykle interesujące kulisy, towarzyszące jego przyjęciu do zespołu Halla. Zaangażowanie dziennikarza miało bowiem dla przedsiębiorstwa Adventure Consultants wymiar de facto marketingouy:

Któregoś popołudnia w bazie zapytałem Halla, dlaczego mu tak zależało na mojej osobie. [...] Najbardziej kuszące było dla niego to, że umowa oferowała hojne warunki promocji i reklamy jego firmy, a reklama była bardzo kosztowna. Zgodnie z zapisami kontraktu Hall zgodził się przyjąć za mnie tylko dziesięć tysięcy dolarów w gotówce zamiast swojej normalnej stawki za uczestnictwo - reszta miała być zrefundowana w postaci bardzo drogich ogłoszeń u magazynie $[. . .]^{30}$.

Owa - nieco paradoksalna sytuacja - w której znalazł się Krakauer, stała się przyczyną konfliktu, jaki wybuchł po tragicznym zakończeniu wyprawy. Zastosowana przez niego metoda dziennikarskiej immersji i będąca jej efektem jawna subiektywizacja przekazu miały bowiem swoją bardzo konkretną cenę. Jako że reporter pozostawał pełnoprawnym członkiem wyprawy, zarzucono mu, że naruszył nie tylko dziennikarski, lecz także górski etos: nie wspomógł w adekwatny sposób towarzyszy znajdujących się w śmiertelnym niebezpieczeństuie. Rozliczano go zatem zarówno z opublikowanego tekstu, jak i - a może przede uszystkim - ze sprzeniewierzenia się zasadom wysokogórskiego braterstwa.

\footnotetext{
27 Ibidem, s. 63.

${ }^{28}$ Ibidem, s. 113.

${ }^{29}$ Ibidem, s. 210.

${ }^{30}$ Ibidem, s. 102.
} 


\section{Paraliteratura}

Analiza paraartystycznego wymiaru pracy Krakauera każe zurócić uwagę przede wszystkim na sam wybór formy książkowej dla rozwinięcia nakreślonej początkowo w reportażu prasouym opowieści. Dziennikarz przyznaje, że pomiędzy pierwotnym tekstem zamieszczonym w czasopiśmie a oddawanym w ręce czytelnika tomem istnieją peune zasadnicze rozbieżności, będące efektem sukcesyunego docierania przez piszącego do nowych faktów. Trzeba przy tym podkreślić, że odmienności między oboma typami publikacji nie sprowadzają się li tylko do samej faktografii; odróżnia je bowiem od siebie także forma, implikująca zgoła odmienne style lektury.

W tomie Wszystko za Everest elementów paraliterackich - inspirowanych poetyką wypracowaną przez twórców spod znaku Nowego Dziennikarstua - czytelnik odnajdzie wiele. Ujawniają się one już u konstrukcji książki, we wprowadzeniu do której bohaterowie zostali przedstawieni w konwencji typowej dla utworów dramaturgicznych. Do tomu Krakauer dołącza kilkustronicową listę uwzględniającą dramatis personae $e^{31}$ - czyli osoby, które w 1996 roku znalazły się na zboczach Everestu. Dziennikarz wymienia na niej także siebie („USA, klient i dziennikarz” ${ }^{32}$ ). W róunie lakoniczny sposób zostają przedstawieni pozostali uczestnicy wypraw: czytelnik dowiaduje się, z jakiego kraju pochodzili, jaką funkcję pełnili w zespole i jaki zawód wykonywali. Taki zabieg ułatwia poruszanie się $w$ gąszczu nazwisk, jest jednak także swoistym mementum, upamiętniającym tych, którzy zdobyli szczyt, ale i tych, którzy - kierowani romantyczną brawurą - już na zausze pozostali na jego zboczach.

Czytając Wszystko za Everest, można zauważyć konsekwentne modelowanie przez Krakauera narracji dziennikarskiej na wzór powieści sensacyjnej. Służą temu przede wszystkim stosowane w tomie retrospekcje i retardacje; wielowątkowość, zabiegi budujące napięcie, takie jak chociażby przerywanie fabuły w kluczowym momencie, by - przykładowo - opowiedzieć czytelnikowi o historycznych aspektach alpinizmu. Dodajmy do tego literackie, oparte na ekfrazie, hiperboli i metaforze barune opisy niezuykłych górskich krajobrazów, które dalekie są od dziennikarskiej rzeczowości i dążenia do obiektywizacji dyskursu. Warto przytoczyć choć jeden charakterystyczny przykład, apoteozujący doznania wzrokowe:

Icefall był więc męczący i przerażający, ale trzeba przyznać, że miał róunież zdumiewający powab. Teraz, w czasie uspinaczki do Obozu I, gdy świt przepędził z nieba ciemności, mogłem zobaczyć, jak potrzaskany lodowiec odsłania swoje widmowe piękno, kryjące się w tym trójwymiarouym obrazie ${ }^{33}$.

Paraliterackie zabiegi służą zuróceniu uwagi czytelnika, wciągnięciu go w historię, której finał w przypadku tekstu non-fiction jest przecież doskonale mu już znany chociażby z ucześniejszych doniesień mediów elektronicznych. Krakauer, zachourując

${ }^{31}$ Por. J. Krakauer, op. cit., s. 15-22.

${ }^{32}$ Ibidem, s. 16.

33 Ibidem, s. 119-120. 
dziennikarski paradygmat autentyczności, obudowuje go typowymi dla literatury chwytami, które mają uczynić przekaz atrakcyjnym. W tym celu burzy chronologię: swą opowieść rozpoczyna nie od opisu przygotowań do wyprawy, lecz od wydarzeń na szczycie. Zdanie: „Stałem na czubku świata, jedną nogą w Chinach, a drugą w Nepalu”34, którym piszący rozpoczyna otwierający książkę rozdział, jest zatem wprowadzeniem czytelnika niejako in medias res i - mówiąc ogólniej - wypełnieniem estetycznych postulatów obowiązujących na gruncie NND.

Jako że kultura popularna opiera się przede uszystkim na emocjach, reporter projektując swój tom - sięga po literackie metody stopniowania napięcia. Tworzy fragmenty celowo udramatyzowane i uykazuje skłonność do parabolizowania. Zdobycie najwyższej góry świata jest $w$ istocie zajęciem mozolnym i długotrwałym, autor posuwa się więc do skondensowania historii, uydobywając z niej najbardziej przejmujące wątki. Uruchamia tym samym melodramatyczny potencjał opisywanej historii. Pieruszy rozdział kończy uwagą, która ma budować napięcie, ale też implikować empatię: „Nikt z nich [wspinaczy atakujących szczyt - przyp. E.Ż.-H.] nie miał pojęcia, że zbliża się straszliwa próba. Nikt nie podejrzewał, że do końca tego długiego dnia liczyć się będzie każda minuta" ${ }^{35}$. Poprzez tego typu retardacje i umiejętną dynamizację opisu książki takie jak Wszystko za Everest (ale także - dodajmy - inne reportaże górskie) mają wzbudzić u czytelnika "głód autentyzmu”36, oferując mu chwilowy dostęp do świata, który od wielu lat rozpala masową wyobraźnię.

Zbliżenie się do konwencji powieściowej wyraża się także w sposobach portretowania bohaterów, którzy - z racji swoich pasji, odwagi i oddania - wpisują się w romantyczny mit szaleńca, marzącego o przełamywaniu kolejnych granic. Ich eskapizm staje się tym, co uwodzi czytelnika. Potwierdzają to słowa Krakauera zanotowane w przedmowie do książki: „Było wiele, bardzo wiele słusznych powodów, żeby nie jechać, ale atakowanie Everestu jest aktem głęboko irracjonalnym, zuycięstwem pożądania nad rozsądkiem"37. Piszącym kieruje zatem nie tylko chęć zrelacjonowania wydarzeń, lecz także romantyczny imperatyw eksplorowania nieznanego.

\section{Podsumowanie}

Obszerne prace tworzone w paradygmacie NND pozostają uspółcześnie atrakcyjną alternatywą dla opierających się na kulcie newsa mediów masowych, oferując czytelnikowi pogłębiony ogląd prezentowanych zdarzeń. Trzeba przy tym podkreślić, że - mimo przedstawionych pokrótce oczywistych zalet omawianego tu nurtu - NND nie aspiruje do roli idealnego modelu uprawiania żurnalistyki: uymaga od reportera czasu, którego nie są u stanie zaguarantować mu uszystkie redakcje; prowokuje piszącego do ciągłego unieważniania granic między życiem prywatnym a zawodowym, prowadząc w efekcie

\footnotetext{
34 Ibidem, s. 25.

35 Ibidem, s. 30.

${ }^{36}$ Por. M. Golka, Gtód autentyzmu, „Opuscula Sociologica” 2016, nr 1, s. 5-13.

37 J. Krakauer, op. cit., s. 13.
} 
do jeszcze silniejszego rozmywania i tak nieostrych już ram dziennikarskiej profesji. NND wikła się też w wewnętrzne sprzeczności: składa odbiorcy obietnicę autentyzmu, a jednocześnie dopuszcza zakładanie masek; opiera się na imperatywie analizowania źródeł, choć uykazuje przy tym silną predylekcję do parabolizacji.

Cechy te - niczym w soczewce - skupia w sobie tom Wszystko za Everest Krakauera, rozbijający genologiczne ramy poprzez łączenie w sobie elementów reportażu intymnego i narracji immersyjnej z paraliterackim sznytem. W analizowanym tekście zauważalna jest dążność do estetyzacji faktów. Cel ten jest realizowany poprzez precyzyjnie dopracowany zestaw chwytów, na który składają się obfitująca w autobiograficzne ustawki retrospektyuna narracja oraz metatekstowe passusy tekstu mityzujące przebieg górskiej wyprawy. Tak wysoce synkretyczna formuła, będąca efektem częściouej adaptacji ucześniejszych, nowodziennikarskich uzorców, każe postawić pytanie o możliwość traktowania reportażu jako narzędzia oswajania osobistych lęków. Analiza Wszystko za Everest pozwala dostrzec zalety i ograniczenia stosowanej przez dziennikarzy perspektywy immersyjnej, służącej dotarciu do (jedynej możliwej, bo w pełni subiektywnej) „praudy” opouieści. Pokazuje także, jak mocno uspółczesny reportaż absorbować może literackie i autobiograficzne wzorce, nie tracąc przy tym swej dokumentarnej formuły.

Przeanalizowawszy możliwość usytuowania reportażu Krakauera w perspektywie głównych założeń NND, zauważyć należy, że paradygmat ten wydaje się niewątpliwie użytecznym - choć przy tym oczywiście dość mglistym i nieostrym - konstruktem teoretycznym, uwypuklającym niezuykle ważną prawidłowość: w historii dziennikarstwa - podobnie jak w historii literatury - pewne idee i koncepty cyklicznie powracają, tworząc sieć intertekstualnych powiązań, wymagających pogłębionej analizy na gruncie komparatystyki mediów. Na przykładzie NND można dostrzec, iż kolejne mediamorfozy to nie tylko ewolucja i rozwój, ale przede uszystkim splot rozmaitych repetycji i innowacji, przyczyniających się finalnie do stworzenia czegoś, co roboczo określić możemy dziennikarskim kanonem. Nowe dziennikarstuo (XIX i XX w.) oraz NND winny być zatem traktowane przede uszystkim swego rodzaju zbiory konwencji, których istnienie warunkuje nie tylko zachowanie kulturowej ciągłości, lecz także pozwala uyznaczyć węzłoue punkty historii mediów.

\section{Bibliografia}

Adamczyk W., Amerykańskie archetypy dziennikarstwa śledczego, Wydawnictuo Naukoue Wydziału Nauk Politycznych i Dziennikarstwa Uniwersytetu im. Adama Mickiewicza, Poznań 2008.

Boynton R., New New Journalism. Conversations with America's Best Nonfiction Writers on Their Craft, Random House, New York 2005.

Bukriejew A., DeWalt G.W., Wspinaczka, przeł. P. Pawlaczek, Wydawnictuo Dolnośląskie, Wrocław 2015.

Burke B., Leckman P., Sturzen A., Van Vlack K., Villanueva H., Lessons from New New Journalism, „Arizona Anthropologist” 2006, nr 17. 
Godzic W., Widzieć świat przez okulary. Dziennikarstwo na serio i to niepoważne [w:] Media.pl. Badania nad mediami w Polsce, red. T. Bielak, G. Ptaszek, Libron, Kraków 2016.

Golka M., Gtód autentyzmu, „Opuscula Sociologica” 2016, nr 1.

Hemley R., A Field Guide for Immersion Writing. Memoir, Journalism, and Travel, The University of Georgia Press, Athens-London 2012.

Krakauer J., Wszystko za Everest, przeł. K. Palmouska, Wydawnictuo Czarne, Wołouiec 2015.

Sabaté Gauxachs A., Slow Media and Religion. The New New Digital Journalism as an Agora for Understanding, Doctoral Thesis. Barcelona 2020, https://wuw.tdx.cat/bitstream/handle/10803/668952/Tesi_Alba_Sabate.pdf?sequence=2\&isAllowed=y (dostęp: 1.12.2020).

Shafer J., „The New New Journalism”: Gonzos for the 21st Century, „The New York Times”, https://www.nytimes.com/2005/03/20/books/review/the-new-new-journalism-gonzos-for-the-21st-century.html (dostęp: 30.11.2020).

Siewior K., Ślimak, śrubeczka i śmierć. Reportaż intymny Mariusza Szczygła, „Teksty Drugie” 2019, nr 6, s. 66-85.

The Muckrakers, red. A. i L. Weinberg, University of Illinois Press, Urbana-Chicago 2001.

Walters P., Ted Conover and the Origins of Immersion in Literary Journalism, „Literary Journalism Studies" 2017, nr 9, s. 8-33.

Wolfe T., The New Journalism, Harper and Row, New York 1973.

Żyrek-Horodyska E., Reportaż biograficzny czy biografia reportażowa? Refleksje genologiczne i analiza przypadku, „Autobiografia” 2018, nr 2, s. 165-185. 